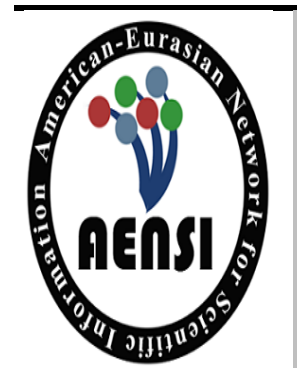

AUSTRALIAN JOURNAL OF BASIC AND APPLIED SCIENCES

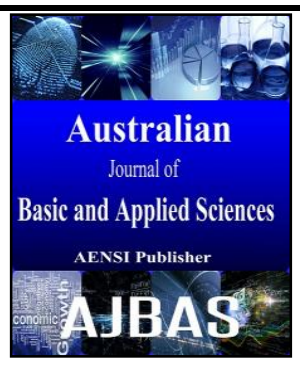

\title{
Evaluation of Time After Leaf Collection As An Influential Factor In Spectroradiometric Measurements
}

${ }^{1}$ Mateus Sabadi Schuh, ${ }^{1}$ José Augusto Spiazzi Favarin, ${ }^{2}$ Luana Dessbesell, ${ }^{1}$ Elisiane Alba, ${ }^{1}$ Juliana Marchesan, ${ }^{1}$ Tiago Luis Badin, ${ }^{3}$ Matheus Morais Ziembowicz, ${ }^{4}$ Rudiney Soares Pereira

${ }^{1}$ Postgraduate in Forestry Sciences, Federal University of Santa Maria, Santa Maria, RS, Brazil.

${ }^{2}$ Postgraduate in Forestry Sciences, Faculty of Natural Resources Managment Lakehead University, Thunder Bay, ON, Canada.

${ }^{3}$ Graduate in Forestry Sciences, Federal University of Santa Maria, Santa Maria, RS, Brazil.

${ }^{4}$ Department rural engineering, Federal University of Santa Maria, Santa Maria, RS, Brazil.

\section{Address For Correspondence:}

Mateus Sabadi Schuh, Federal University of Santa Maria, Posgraduate in Forestry Sciences, rural engineering department, Av. Roraima, 1000, Camobi, 97105-900, Santa Maria, RS, Brazil.

Phone: +55(55)99038567; E-mail: mateuschuh@gmail.com

\section{A R T ICLE INFO}

Article history:

Received 12 October 2017

Accepted 22 November 2017

Available online 6 December 2017

Keywords:

vegetation indexes, spectral response, radiometric measurement, vegetative vigor.

\begin{abstract}
A B S T R A C T
Background: Spectroradiometric studies involving the collection of vegetative material in the field and subsequent radiometric measurements in the laboratory are susceptible to limitations due to the loss of information related to the temporal lapse between collection and analysis. Objective: Thus, the objective of this study is to identify which spectral intervals and which vegetation indices present higher sensitivity to the postharvest time of leaves extracted from an individual of the species Eucalyptus saligna Smith.Material and Methods: The material was collected in the field, and the radiometric measurements were performed in laboratory using a FieldSpec $® 3$ spectroradiometer, with an interval of 15 minutes, during 10 hours of observation. Epectral bands and indexes with frequent use in vegetation studies that evolve both in situ spectroradiometry techniques and orbital sensor surveys were selected. For each of the variables, were computed the averages of the 40 observations over the time and Tukey's test of means comparison was applied pair by pair. Results:In general, bands and indices that respond directly by vegetative vigor and photosynthetic activity showed higher latency on significance in relation to the beginning of the observations, as showed by SR, NDVI and REP, with 5, 5, 25, 9.75 hours respectively. However, the variables related to the internal scattering due to the tissue rupture and water loss were more sensitive to the experiment, especially the TVI index and the NIR band, which demonstrated significant results after 1.25 and 1.5 hours of the beginning of the measurements. Conclusion:The listed variables allowed the detection of foliar degradation over time after collection at different levels of sensitivity. For the latter it is recommended that in similar experiments it is timely to observe the waiting time between the extraction of leaves and the performance of the radiometric measurements in order to avoid possible loss of information.
\end{abstract}

\section{INTRODUCTION}

The growing demand for forest products causes the productive sector to seek technologies that provide more information about the characteristics of the plots, since these areas require periodic monitoring in order to obtain a quality product (Bonete et al., 2016; Trevisan et al., 2016). Over the last decades, remote sensing tools have aided in the understanding of natural phenomena, especially in the characterization of the interaction processes between the vegetation and the surrounding environment. The study of the interaction between the electromagnetic energy used in the spectral characterization of the vegetation cover has been carried out in different types of approach that involve from surveys from orbital sensors, such as in loco measurements with

Open Access Journal

Published BY AENSI Publication

(C) 2017 AENSI Publisher All rights reserved

This work is licensed under the Creative Commons Attribution International License (CC BY).

http://creativecommons.org/licenses/by/4.0/

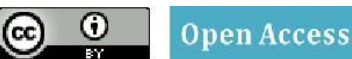

To Cite This Article: Mateus Sabadi Schuh, José Augusto Spiazzi Favarin, Luana Dessbesell, Elisiane Alba, Juliana Marchesan, Tiago Luis Badin, Matheus Morais Ziembowicz, Rudiney Soares Pereira., Evaluation of Time After Leaf Collection As An Influential Factor In Spectroradiometric Measurements. Aust. J. Basic \& Appl. Sci., 11(14): 17-24, 2017 
spectroradiometers. According to Silva et al. (2012), spectroradiometry proves to be a tool that allows the detection of spectral response through direct contact with the target, and can be performed in the laboratory, minimizing the interference of the environmental factors present in the surveys of other types of sensors.

Several applications of foliar spectrometry have been developed, such as the study of plant phytosanity (Jusoff et al., 2010; Lippert et al., 2015), nutritional assessment (Mokhele \& Ahmed, 2010; Kakani \& Reddy, 2010) (Gamron et al., 2008), besides the evaluation of physiological parameters (Garriga et al., 2014, Fernández et al., 2015). According to Tsai \& Philpot (1998), the spectroradiometry data collected in the laboratory environment have controlled conditions of intensity and spectral distribution of illumination, as well as visualization of the geometry, and the sample is generally prepared to improve the detection of the target substance.

At times, the target of interest is located in distant locations that are difficult to access relative to radiometric measurements place, which involves the extraction of leaves from the mother plant and, consequently, a time gap between collection and readings. According to Sanches et al. (2003), after being extracted from the mother plant, the leaf begins a senescence process, characterized by loss of water, degradation of the cellular constituents and modifications of the foliar mesophyll structure.

Some experiments attest the use of spectroradiometric data in the detection of foliar degradation after collection of the mother plant. Göergen et al. (2009), found significant differences for the visible and near infrared bands at 0, 4, 8 and 72 hours after collection of Erythrina crista-galli L. leaves. For the same spectral intervals, Pinto et al. (2011) obtained significant differences during the process of senescence of elephantgrass (Pennisetum purpureum Schum.), with interval of 3 measurements in the first 6 hours and after 20, 22 and 24 hours of leaf collection. Sanches et al. (2003) found significant changes in reflectance, transmittance and absortance values in different spectral bands over time (0,7 and 72 hours) in ligustum (Ligustrum sp.) and fedegoso (Cassia sp.). Like Sousa et al. (1996) for Eucalyptus grandis at times 0, 3, 5, 6, 7, 8, 23 and 27 hours after collection.

The fact that foliar degradation due to leaf extraction is significant under the spectroradiometric approach raises the interest in the evaluation of the time variable as a factor that may cause the loss of information about the objects under analysis. This type of inference can diagnose the possible limitations in spectroradiometric studies involving the collection and displacement of field material for laboratory analysis. In this context, the present study aims to identify which spectral intervals and which vegetation indices present higher sensitivity to the time after collection of leaves extracted from an individual of the species Eucalyptus saligna.

\section{MATERIALS AND METHODS}

\section{Location of the study area:}

The vegetative material analyzed was collected at the Campus of the Federal University of Santa Maria -

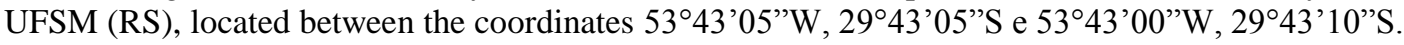

\section{Materials:}

Radiometric measurements were performed using the FieldSpec®3 spectroradiometer coupled to the RTS3ZC3 integrating sphere, internally coated by Spectralon material that resembles a perfectly diffused reflectance Lambertian surface.The readings were recorded and stored by a microcomputer connected to the spectroradiometer.

The original file from the spectroradiometer consists of a binary extension containing the reflectance factors across the range of recorded spectrum (350 to $2500 \mathrm{~nm}$ ). These files were converted by ASD WiewSpec Pro software (version 4.05) in text format, for later processing and analysis in R software (version 3.3.3).

\section{Methods:}

\section{Material collection and radiometric measurements:}

A representative adult adult of the species Eucalyptus saligna was selected, with good sanitary and nutritional characteristics. They were collected, in the periphery of the canopy, branches located along the four quadrants, in relation to sun exposure. These were packed in plastic bags and taken to the laboratory. The collection was performed at the highest turgor stage of the leaves, at the beginning of the morning, at approximately $7 \mathrm{~h}$. In the laboratory, a sample of 30 healthy leaves with the same stage of development was selected for the readings.

The radiometric measurements were performed by the Remote Sensing Laboratory of UFSM. Preliminary to spectrum measurements, the spectroradiometer was calibrated with Spectralon-type plates coupled to the recording terminals of the integrator sphere.

During the measurements, the leaves were positioned in such a way that only the adaxial leaf blade remained exposed to the reading terminal of the sphere, avoiding measurements on the central rib of the same. 
For each of the 30 samples, three measurements were performed at different positions on the ventral surface. This procedure was repeated every 15 minutes for the period of 10 hours, totaling 40 observations.

\section{Analyzes of spectroradiometric variables:}

In the $\mathrm{R}$ software, the reflectance spectra were segmented according to the bands shown in Table 1 . The mathematical procedure to obtain vegetation indices took into account the definitions presented in Table 2 . The selection criterion for such bands and indices was the frequent use of these variables in vegetation studies involving both in situ spectroradiometric techniques and orbital sensor surveys.

For each of the variables, the averages of the 40 observations were computed over time and Tukey's test of means comparison was applied pair by pair. This procedure returned as a result the time corresponding to the lowest mean significantly different from the first measurement (indicator used to evaluate the response of the variables to the experiment).

Table 1: Spectral bands used in data analysis.

\begin{tabular}{|l|l|l|}
\hline Bands & Spectral reange (nm) & Autor \\
\hline Blue & 450 a 520 & (Jensen, 2011) \\
\hline Green & 520 a 600 & (Jensen, 2011) \\
\hline Red & 630 a 690 & (Meneses \& Netto, 2001) \\
\hline NIR (Near Infrared) & 700 a 1100 & (Meneses \& Netto, 2001) \\
\hline SWIR 1 (Short Wavelenght Infrared 1) & 1100 a 1350 & (Meneses \& Netto, 2001) \\
\hline SWIR2 (Short Wavelenght Infrared 2) & 1400 a 1800 & \\
\hline
\end{tabular}

Table 2: Vegetation indices used in data analysis.

\begin{tabular}{|c|c|c|}
\hline Index & Mathematical equation & Author \\
\hline $\begin{array}{l}\text { TVI } \\
\text { Triangular } \\
\text { Vegetation Index }\end{array}$ & $\mathrm{TVI}=0,5(120(750 \mathrm{~nm}-550 \mathrm{~nm}))-200\left(670 \mathrm{~nm}-550_{\mathrm{nm}}\right)$ & $\begin{array}{l}\text { Broge \& } \\
\text { Leblanc (2000) }\end{array}$ \\
\hline $\begin{array}{l}\text { TCARI } \\
\text { Reflectance Index for } \\
\text { Chlorophyll Absorption }\end{array}$ & $\operatorname{TCARI}=3\left[\left(\rho_{700}-\rho_{670}\right)-0,2\left(\rho_{700}-\rho_{550}\right)\left(\frac{\rho_{700}}{\rho_{670}}\right)\right]$ & $\operatorname{Kim}_{(1994)}$ et $a l$. \\
\hline $\begin{array}{l}L W C I \\
\text { Relative Content Index of } \\
\text { Leaf Water }\end{array}$ & $\begin{array}{l}\qquad \mathrm{LWCI}=\frac{\ln \left[1-\left(\rho_{820}-\rho_{1600}\right)\right]}{-\ln \left[1-\left(\rho_{820}-\rho_{1600}^{\mathrm{FT}}\right)\right]} \\
\rho_{1600}^{F T}=\text { Folha completamente túrgida }\end{array}$ & $\begin{array}{l}\text { Hunt } \\
\text { Rock.(1989) }\end{array}$ \\
\hline $\begin{array}{l}\text { NVI } \\
\text { New Vegetation Index }\end{array}$ & $\mathrm{NVI}=\frac{\rho_{777}-\rho_{747}}{\rho_{673}}$ & $\begin{array}{l}\text { Gupta } \\
(2001)\end{array}$ \\
\hline $\begin{array}{l}S R \\
\text { Simple Ratio }\end{array}$ & $\mathrm{SR}=\frac{\rho_{\text {nir }}}{\rho_{\text {red }}}$ & $\begin{array}{l}\text { Birth } \\
\text { NcVey(1968) }\end{array}$ \\
\hline $\begin{array}{l}N D V I \\
\text { Normalized Difference } \\
\text { Vegetation Index }\end{array}$ & $\mathrm{NDVI}=\frac{\rho_{\text {nir }}-\rho_{\text {red }}}{\rho_{\text {nir }}+\rho_{\text {red }}}$ & 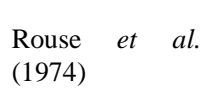 \\
\hline $\begin{array}{l}R E P \\
\text { Red-edge Position }\end{array}$ & $\begin{array}{c}\text { REP }=700+40\left[\frac{\rho_{\text {red edge }}-\rho_{700}}{\rho_{740}+\rho_{700}}\right] \\
\rho_{\text {red edge }}=\frac{\rho_{670}+\rho_{780}}{2}\end{array}$ & Clevers (1994) \\
\hline
\end{tabular}

\section{RESULTS AND DISCUSSIONS}

In order to aid in the interpretation of the statistical analyzes, the absolute and relative increment curves of the reflectance of the Eucalyptus saligna leaves, as well as the trends observed in the different measurement periods for the vegetation indices are presented. 
The exploratory analysis of the spectral response curves allows to clearly detect the increase in the reflectance factor of the leaves over time, along the spectral range recorded by the spectroradiometer. Figure 1 shows the reflectance curves for the readings for the times $0 \mathrm{~h}, 01 \mathrm{~h}, 5 \mathrm{~h}$ and $10 \mathrm{~h}$ after the leaves were collected.

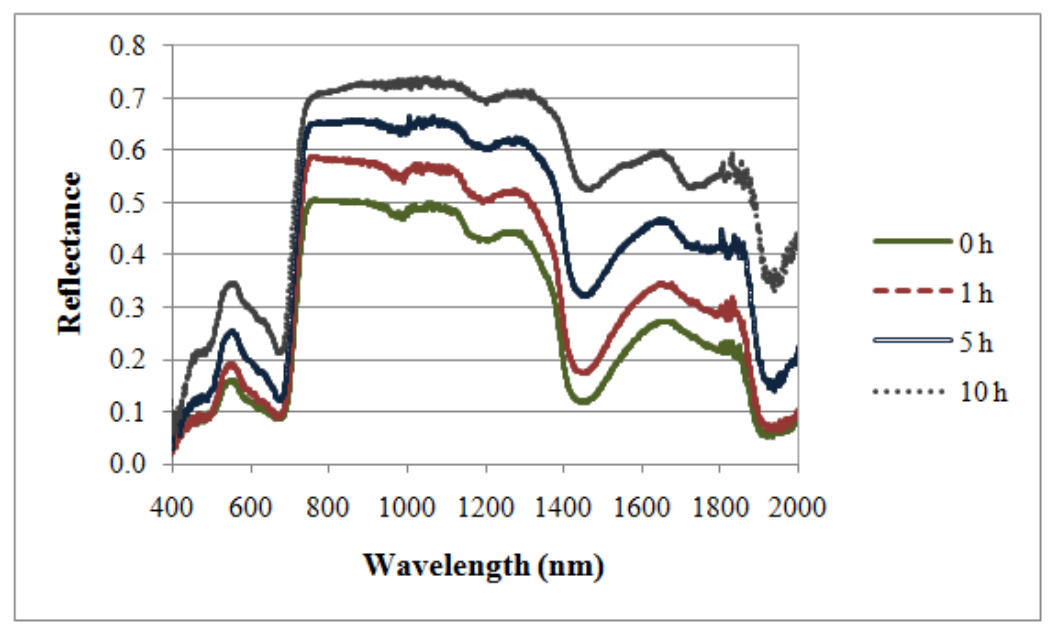

Fig. 1: Reflectance curves of Eucalyptus saligna leaves at different times post-collection.

The Figure 2 shows the relative increase of reflectance in each of the spectral bands of the visible region, near infrared and medium infrared. The curve exposed by the SWIR2 band presented a pattern that dissociates from the others since the beginning of the measurements. The bands of blue, green, red, NIR and SWIR2 showed similarities in the growth trends up to 4 hours after leaf collection, from which, evidenced differences in the behavior of the curves. In an intermediate range, the bands of the visible region are observed, which presented values between 130 and $160 \%$. The smallest increments were verified for the NIR band with 50\% and SWIR1 with $60 \%$.

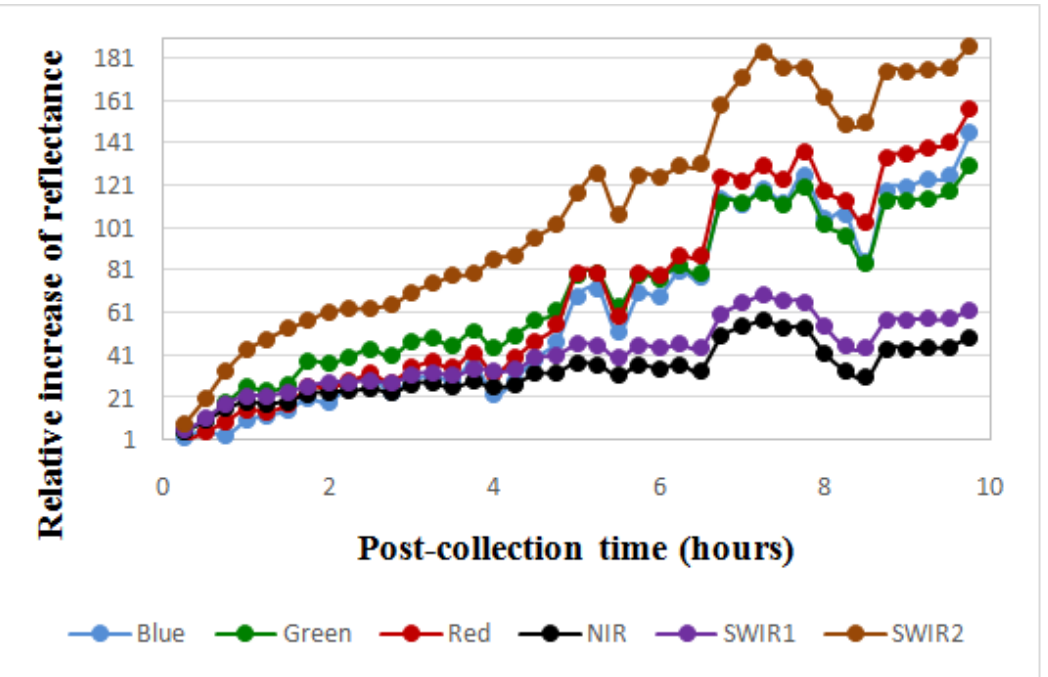

Fig. 2: Relative increase in reflectance of different spectral bands throughout the experiment.

Regarding vegetation indexes, Figure 3 shows the mean results for each of the 40 observations. The results evidenced clear trends with patterns described by specific mathematical adjustments, with the exception of the TVI and NVI indexes, which presented a less uniform behavior over time and, therefore, a low degree of adjustment. 

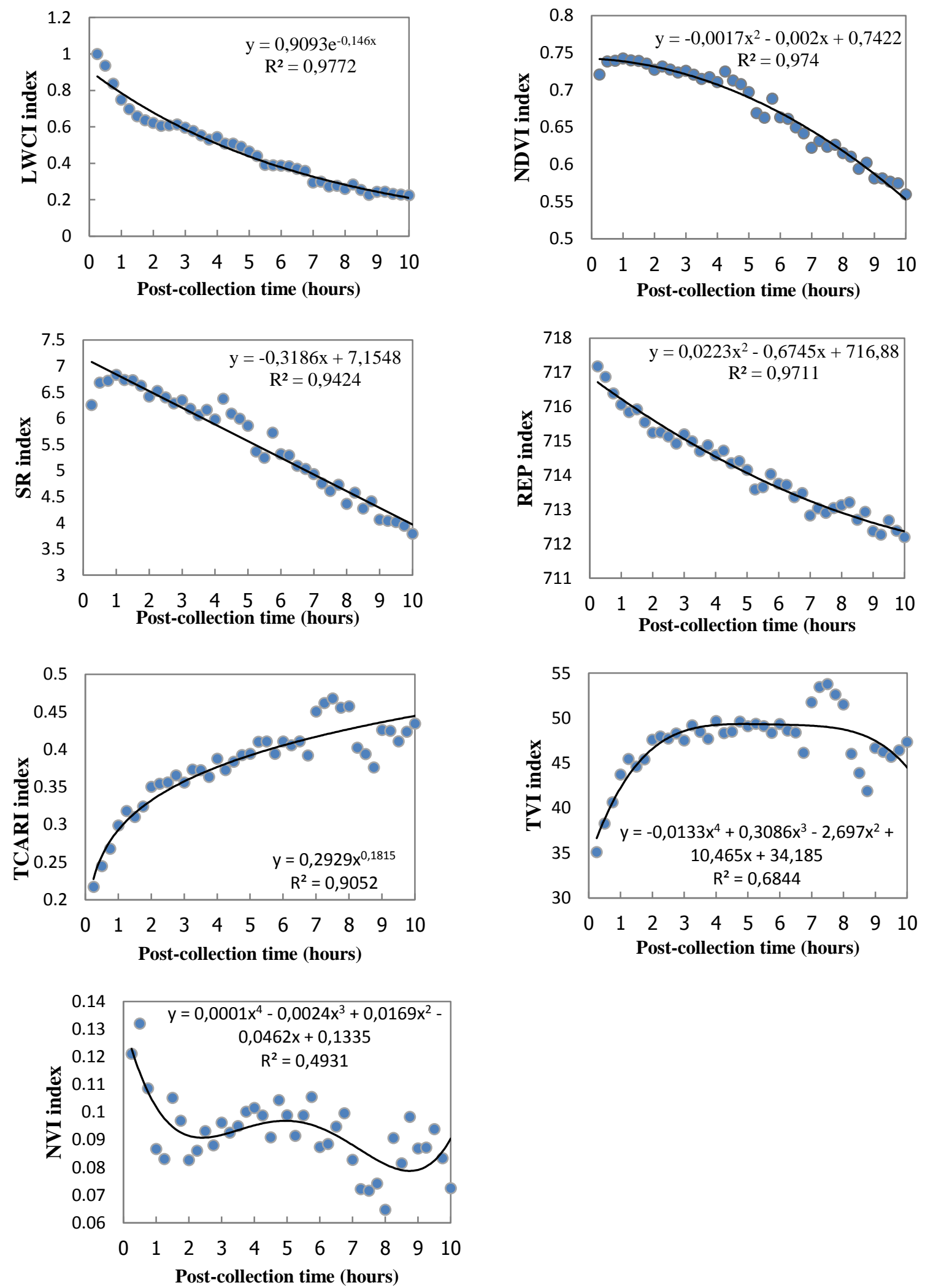

Fig. 3: Average results of vegetation indices over the 10 hours of the experiment.

When analyzing the trend curve of the LWCI index, it was observed the decrease of the index values, especially in the first hour of observation (although the significance occurred after 3 hours), and could be related to the loss of water, since this index expresses the water content in the leaves.

In Table 3, the results of the statistical analyzes of the spectral variables evaluated (spectral bands and vegetation indices) are presented. The TVI index presented a more sensitive response to the experiment, with a 
significant difference after 1 hour and 15 min of the beginning of the measurements, followed by the NIR band, with 1 hour and $30 \mathrm{~min}$.

The bands that make up the visible region presented significance after 3 hours. The SR and NDVI indices showed similarities, with a significant difference in 5 hours and 5 hours and 15 min, respectively. The REP index, on the other hand, presented lower sensitivity to the time after the leaves' collection, with significance from 9 hours and $15 \mathrm{~min}$.

Table 3: Statistical analysis of the spectral variables evaluated.

\begin{tabular}{l|l|l}
\hline Vegetation index & Fvalue* & Significant difference (Horas) \\
\hline TVI & 26,20 & 1,25 \\
NIR & 35,31 & 1,50 \\
TCARI & 41,73 & 2,15 \\
SWIR1 & 45,48 & 2,50 \\
LWCI & 6,420 & 3,00 \\
NVI & 5,489 & 3,00 \\
Azul & 31,02 & 3,00 \\
Verde & 35,52 & 3,00 \\
Vermelho & 32,62 & 3,00 \\
SWIR2 & 67,52 & 3,00 \\
SR & 27,42 & 5,00 \\
NDVI & 28,96 & 5,25 \\
REP & 8,009 & 9,25 \\
\hline Pr(>F): $<2 \times 10^{-16}$ (Probability & (tablar & \\
\hline
\end{tabular}

$* \operatorname{Pr}(>\mathrm{F}):<2 \times 10^{-16}$ (Probability of tabular value to be greater than $\mathrm{F}$ )

It was observed that, during the experiment, the values of reflectance were increased, especially in the near and middle infrared region (SWIR1 and SWIR2), accompanied by smoothing the water absorption features centered at 900, 1200, 1500 and between 1900 and $2000 \mathrm{~nm}$.

The Eucalyptus saligna spectral response showed an increase in the reflectance values with the increase in time after the leaves were collected. This behavior was observed along the spectral range used. This result corroborates a study carried out by Carter (1991), who, when analyzing the influence of water on leaves of Magnolia grandiflora, observed a higher reflectance in the range of 400 to $2500 \mathrm{~nm}$ as the leaf moisture content decreased.

The reduction of the energy absorption in the visible region is associated with reduced photosynthesis, since this region is controlled by leaf pigments responsible for this process, such as chlorophyll a and b, and carotenoids (Jensen, 2011; Ponzoni et al., 2012). However, the decrease in chlorophyll quantification in stressed plants may be a response caused by water deficiency, which degrades the photosynthetic pigments (Genc et al., 2013).

In this sense, Genc et al. (2013) define that changes in foliar morphology, being these in the concentrations and amount of foliar pigments have a strong influence on the foliar spectral properties. According to Ponzoni et al. (2012) chemically it is expected that the decrease of the amount of water causes the degradation of proteins and photosynthetic pigments, which makes the leaf less able to absorb electromagnetic radiation in the visible region and, consequently, reduction of photosynthesis.

Water stress in plants causes changes in the chemical-pigment concentrations, area and cellular structure of the affected plant tissues (Mirik, 2012). Thus, the internal structure of the leaves is responsible for the high reflectance in the near infrared region, due to internal scattering (Jensen, 2011). Ponzoni et al. (2012) emphasize that the decrease in the water content of the cells makes them more prismatic, which contributes to the formation of faces critical to the deviation of the electromagnetic radiation trajectory, besides leaving the internal structure less compact, increasing the scattering and, consequently, reflectance of the leaves in this region.

The average infrared region is controlled by the leaf water content, so as the time between leaf collection and spectral response readings increased, the portion of the reflected electromagnetic radiation was higher in the medium infrared region, especially from $1300 \mathrm{~nm}$, showing gradual losses of water inside the cells after the leaf collection. According to Jensen (2011), as the leaf water decreases, more intense the incident energy in the medium infrared is spread, resulting in higher reflectance values in that region.

The SWIR2 band, which comprises the spectral range from 1400 to $1800 \mathrm{~nm}$, showed a higher reflectance increment when compared to the other bands, showing larger changes as a function of the time of collection of the leaves under the spectral response. Similar behavior was obtained by Carter (1991), who observed that the average infrared region in the range of 1300-2500 $\mathrm{nm}$ showed the highest reflectance, caused by loss of leaf moisture when compared to the visible and near infrared region.

The TVI vegetation index describes the energy absorbed by the pigments, including the green, red and NIR bands. The combination of three different bands resulted in a greater sensitivity in relation to the collection time of Eucalyptus saligna leaves. According to Jensen (2011), the TVI index relates the absorption of chlorophyll in green and red with the high reflectance of near infrared. The same reasoning can be applied to the TCARI, which, although it is used to translate the amount of chlorophyll in the leaves, in its design, besides the 
absorption bands of the visible, also relates the reflectance of the near infrared start in the $700 \mathrm{~nm}$ range. On the other hand, the REP index presented a lower sensitivity to the time after harvesting of the leaves of Eucalyptus saligna, demonstrating a smaller loss of information contained in the spectral response of the target, when compared to the other spectral variables. The NIR and SWIR1 bands presented significance in a shorter time, while the blue, green, red and SWIR2 bands, which were identified as the highest percentages of reflectance increase, showed significant differences over a longer analysis time, being less sensitive to the material collection time.

Visible bands and indices that respond directly to vegetative vigor and photosynthetic activity (SR, NDVI and REP) took longer to produce significant results. This latency can be explained by the defense mechanisms of plants. According to Taiz \& Zeiger (2004), in the initial stages of water stress, the efficiency of water use may increase with the closure of stomata, with a higher amount of $\mathrm{CO}^{2}$ absorbed per unit of transpirated water, since stomatal closure inhibits transpiration more than decreasing intercellular $\mathrm{CO}^{2}$ concentrations. However, as the cell dehydration becomes more severe, the metabolism of the mesophyll is impaired and the efficiency of water use decreases and, as a consequence, photosynthesis is inhibited.

Sousa et al. (1996), when evaluating the influence of time and type of storage of Eucalyptus grandis leaves extracted from the mother plants on their spectral response, detected a similar pattern for significance. At ambient temperature, the stress in the near infrared region began to be detected after 3 hours of collection, whereas in the visible, significant differences were noted only 23 hours later.

\section{Conclusion:}

The proposed experimental design allowed the detection of foliar degradation over time after the collection of the mother plant at different levels of sensitivity. In general, the bands and indices known to be related to the internal scattering as a function of tissue disintegration and water loss, were more sensitive to the experiment. On the other hand, the variables that respond directly by vegetative vigor and photosynthetic activity showed a higher latency for significance.

At the operational level, in similar experiments, it is opportune to observe the waiting time between the extraction of the leaves and the accomplishment of the radiometric measurements, especially in the case of the TVI index and the NIR band, which were the most time sensitive variables post-collection, translated by the short period into the significant results. For NDVI, SR and mainly REP, there is a greater time frame until there is a significant loss of information.

\section{REFERENCES}

Birth, G.S. and G. McVey, 1968. Measuring the Color of Growing Turf with a Reflectance Spectroradiometer. Agronomy Journal, 60: 640-643.

Bonete, I.P., K.H.P. Deus, C.C. Benin, A.T.A. Garrett, A.N. Dias, L.F. Watzlawick, 2016. Identify of hypsometric and volumetric models for Eucalyptus benthamii grouped by planting spacing. Australian Journal of Basic and Applied Sciences, 10(13): 101-107.

Broge, N.H. and E. Leblanc, 2000. Comparing prediction power and stability of broadband and hyperspectral vegetation indices for estimation of green leaf area index and canopy chlorophyll density. Remote Sensing of Environment, 76: 156-172.

Carter, G.A., 1991. Primary and secondary effects of the water content on the spectral reflectance of leaves. American Journal of Botany, 78(7): 916-924.

Clevers, J.G.P.W., C. Büker, H.J.C. Van Leeuwen and B.A.M. Bouman, 1994. A framework for monitoring crop growth by combining directional and spectral remote sensing information. Remote Sensing Environment, 50: $161-170$.

Fernández, A.B.G., J.R.R. Pérez, V. Marcelo and J.B. Valenciano, 2015. Using field spectrometry and a plant probe accessory to determine leaf water content in commercial vineyards. Agricultural water management, 156: 43-50.

Gamon, A.J. and B. Bond, 2013. Effects of irradiance and photosynthetic downregulation on the photochemical reflectance index in Douglas-fir and ponderosa pine. Remote Sensing of Environment, 135: 141149.

Garriga, M., J.B. Retamales, S. Romero-Bravo, P.D. Callegari and G.A. Lobos, 2014. Chlorophyll, anthocyanin, and gas exchange changes assessed by spectroradiometry in Fragaria chiloensis under salt stress. Journal of Integrative Plant Biology, 56(5): 505-515.

Genc, L., M. Inalpulat, U. Kizil, M. Mirik, S.E. Smith and M. Mendes, 2013. Determination of water stress with spectral reflectance on sweet corn (Zea mays L.) using classification tree (CT) analysis. ZemdirbysteAgriculture, 100(1): 81-90.

Göergen, L.C., E.F. Berra, A.C.P. Benedetti, C. Brandelero, K.S. Backes and R.S. Pereira, 2009. Caracterização espectral de folhas e influência do tempo após a coleta de folhas na reflectância de Erythrina 
crista-galli L. In: SIMPÓSIO BRASILEIRO DE SENSORIAMENTO REMOTO, 14., 2009, Natal. Anais... Natal, SBSR, pp: 2753-2759.

Gupta, R.K., D. Vijayan and T.S. Prasad, 2001. New hyperspectral vegetation characterization parameters. Advances in space research, 28(1): 201-206.

Hunt, E.R. and B.N. Rock, 1989. Detection of changes in leaf water content using near- and middle-infrared reflectances. Remote Sensing of Environment, 30: 43-54.

Jensen, J.R., 2011. Sensoriamento Remoto do Ambiente: uma perspectiva em recursos terrestres. Tradução José Carlos Neves Epiphanio (coord.), São José dos Campos, Parêntese, 2ed., p: 598.

Jusoff, K.H., M.M. Yusoff and N.H.M. Ali, 2010. Spectral signatures of leaf fall diseases in Hevea brasiliensis using a handheld spectroradiometer. Modern Applied Science, 4(2): 78-84.

Kakani, V.G. and K.R. Reddy, 2010. Reflectance properties, leaf photosynthesis and growth of nitrogen deficient big bluestem (Andropogon gerardii). Journal of Agronomy \& Crop Science, 196(5): 379-390.

Kim, M.S., C.S.T. Daughtry, E.W. Chappelle, J.E. McMurtrey and C.L. Walthall, 1994. The use of high spectral resolution bands for estimating absorbed photosynthetically active radiation (Apar). Proceedings of the 6th Symposium on Physical Measurements and Signatures in Remote Sensing, Val D'Isere, France, pp: 299306.

Lippert, D.B., A.C.P. Benedetti, M.F.B. Muniz, R.S. Pereira, C.A. Biernaski Junior, E. Finkenauer and E.F. Berra, 2015. Comportamento espectral de folhas de Eucalyptus globulus (Labill.) atacadas por Mycosphaerella spp. nas regiões do visível e do infravermelho próximo do espectro eletromagnético. Ciências Florestais, 25(1): 211-219.

Manevski, K., I. Manakos, G.P. Petropoulos and C. Kalaitzidis, 2011. Discrimination of common Mediterranean plant species using field spectroradiometry. International journal of applied earth observation and geoinformation, 13(6): 922-933.

Meneses, P.R. and J.S. Madeira Netto, 2001. Sensoriamento Remoto: reflectância dos alvos naturais. Brasília, Editora Universidade de Brasília, p: 262.

Mirik M., R.J. Ansley, G.J. Michels Jr. and N.C. Elliott, 2012. Spectral vegetation indices selected for quantifying Russian wheat aphid (Diuraphis noxia) feeding damage in wheat (Triticum aestivum L.). Precision Agriculture, 13: 501-516.

Mokhele, T.A. and F.B. Ahmed, 2010. Estimation of leaf nitrogen and silicon using hyperspectral remote sensing. Journal of Applied Remote Sensing, 4(1): 043560-043560-18.

Pinto, L.M., G.RC. Souza, L.P. Camargo, L.A. Reginatto, S.P.F. Luiz, S.T.D. Cruz, S.M.G. Silva, W.D.B. Bilhalva and R.S. Pereira, 2011. Caracterização espectral de folhas e influência do tempo após a coleta de folhas na reflectância de duas cultivares de Pennisetum purpureum Schum. In: SIMPÓSIO BRASILEIRO DE SENSORIAMENTO REMOTO, 15., 2011, Curitiba. Anais... Curitiba, SBSR, pp: 362-368.

Ponzoni, F.J., Y.E. Shimabukuro and T.M. Kuplich, 2012. Sensoriamento remoto aplicado ao estudo da vegetação. 2. ed. São José Dos Campos, Saraiva, p: 160.

Rouse, J.W., R.H. Haas, D.W. Deering and J.A. Schell, 1974. Monitoring the vernal advancement and retrogradation (green wave effect) of natural vegetation. College Station: Texas A\&M University, p: 87.

Sanches, I.D., L.O. Anderson, E.H.M. Rojas and C.G. Oliveira, 2003. Influência do tempo após a coleta de folhas na reflectância e transmitância. In: Simpósio Brasileiro de Sensoriamento Remoto, 11., 2011, Belo Horizonte. Anais... Belo Horizonte, SBSR, pp: 2605-2612.

Silva, E.A, G.P. Marangon, L. Dessbesell, W.W. Morais, D.B. Lippert and R.S. Pereira, 2012. Caracterização espectral na reflectância de Eucalyptus grandis. Floresta, 42(2): 285-292.

Sousa, C.L., M.C. Ribeiro and F.J. Ponzoni, 1996. Influência do tempo e do tipo de armazenamento na reflectância espectral de folhas de Eucalyptus grandis "ex-situ". Revista Árvore, 20(2): 255-265.

Tsai, F. and W. Philpot, 1998. Derivative Analysis of Hyperspectral Data. Remote Sensing of Environment, 66: 41-51.

Taiz, L. and E. Zeiguer, 2004. Fisiologia Vegetal. 3 ed., Porto Alegre, Ed. Artmed, pp: 613-642.

Trevisan, R., C.R. Haselein, E. Eloy, B.O. Caron, R. Balbinot, 2016. Dendrometric characteristics of Eucalyptus grandis submitted to thinning. Australian Journal of Basic and Applied Sciences, 10(10): 45-51. 